\title{
The Eighteenth Century and the Rise of the English Novel
}

\author{
Mariwan N. Hasan \\ English Department, University of Sulaimani, Sulaimani-Kurdistan, Iraq
}

\section{Email address}

Mariwan152@live.com

\section{To cite this article:}

Mariwan N. Hasan. The Eighteenth Century and the Rise of the English Novel. International Journal of Literature and Arts. Vol. 3, No. 2, 2015, pp. 18-21. doi: 10.11648/j.ijla.20150302.12

\begin{abstract}
It is not by chance that the English Novel dates back to the Eighteenth century. This does not imply that nothing existed in the form of a novel before 1700. Then, Daniel Defoe made novel come to existence, completely. Nothing comes from nothing, even the greatest masterpieces of literature starts off from what was available from the previous eras. The novelist in the Eighteenth century had on one hand, the medieval romance and its successors; the courtly novel of Italy and France and the English stories. The Sixteenth and Seventeenth centuries were developed and grown out of some important sources: Lyly's Euphues, Sidney's Arcadia and Green's Menaphon. On the other hand, the rogue novels and the Picaresque tradition were two other significant factors to the rise of the English Novel. Certain other factors were helpful to the rise of the English novel; from them; translations from the classics such as The Golden Ass of Petronius, Boccaccio as well as the authorized version of the Bible.
\end{abstract}

Keywords: The Rise of The English Novel, Early English Novelists \& Daniel Defoe

\section{Introduction}

It is possible to say that the novel as a literary genre emerged in the beginning of the eighteenth century. The industrial revolution can be said, paved the way to the rise of the middle-class and it also created a demand for people's desire for reading subjects related to their everyday experiences. The novel, therefore, developed as a piece of prose fiction that presented characters in real-life events and situations. Daniel Defoe's Robinson Crusoe and Henry Fielding's Tom Jones are some of early English novels. The novel is realistic prose fiction in such a way that it can demonstrate its relation to real life.

The eighteenth-century great novels are semi anti-romance, or it was the first time that the novel emerged and distributed widely and largely among its readers; reading public. Moreover, with the increase of the literacy, the demand on the reading material increased rapidly, among well-to- do women, who were novel readers of the time.

Thus, theatre was not such feasible form of entertainment but novel was due to its large audience and its spread all over the land in country-houses. In other words, middle was such an important factor behind the growth of the novel as a new form of art.

The social and intellectual currents of the age were linked for creating something new and different. Those who carried out the action became individualized; they were interpreted in and all their complexity and the social pressure on them were minutely detailed. When people wanted to hear stories of those who are not too different from themselves, in a community recognizably a kin to their own, then the novel was born.

There are also other reasons and factors that influenced the rise of the English novel. The invention of traveling library was one of those and via trade; it was developed more than before. The social milieu and social condition of the life of the middle-class were very much affected by the rise of the English novel. These people in the eighteenth century were acquiring their education, what they were acquiring was less exclusively classical in context than the education of the upper-class. Women readers were considered as a crucial factor in providing readership. A better education for women was coincided with a period of a greater leisure for women in middle and upper ranks. The greater leisure for women left a time space, which needed to be filled in. Men were also educated and had an intension to see beyond the narrow local interests and profession to an inspired motivation. Both men and women were receptive to literary forms, which would open up to them recent and real worlds outside their own world.

The reproduction of newspapers in the eighteenth century is evidence on the rise of the novel and so is the popularity of 
the periodicals. The seed of Richardson's Pamela was a plan to write a series of letters, which provided examples of the correct way of continuing in various delicate social situations. The novelists also believe that their task is not only to inform but also to indicate morality. Middle-class people considered usefulness significant; this would include moral usefulness. The readers were introduced by the novelists to new social worlds, providing the moral framework within which that behaviour. The novel was dealing with the immediate details as no earlier fiction has been, as a result, it becomes long.

As a result, in the eighteenth century, many reasonable changes took place in strange plots and ideas of heroic tragedy. Defoe described 'The Great Plague of London' in the journal of the plague year (1722), then his Robinson Crusoe (1719), a better and more famous book. The story of the book relied on the real life event. It is about the story of Alexander Selkirk, a Scottish sailor who quarreled with his captain, was, in fact, put into the island of Juan Fernandez near Chile, and he lived there alone for four years.

Richard Steel and Joseph Addison worked together to produce The Tatlar, a collection of essays without too much ornament, which helped in the production of the novel. Dr. Samuel Johnson's Dictionary was written in (1755). Some of the best English letters were written during this century. Swift and Defoe wrote stories of adventure. A good prose style was made ready to use in 'Spectator' by both Dryden and Chesterfield. And Samuel Richardson wrote Pamela in (1740); a real novel, which was written in the form of letters. When these letters appeared women were excited to read them and listen to the readers of those letters.

Richardson also wrote Clarissa and also Fielding's great novel appeared in the name of Tom Jones in (1749). The fourth novelist of this time was Laurence Sterne. His astonishing books are as confusing as life. Another important novel of the time is The Vicar of Wakefield (1761-2), by Oliver Goldsmith. Below are several factors that contributed towards the rise of the English novel: The rise of the literacy, the novel is essentially a written form, unlike poetry, which exists for centuries prior to the development of writing, and still flourishes in oral cultures today. There have been cases of illiterate people gathering to hear novel read- part of Dickens's audience was of this sort and daring the Victorian period the habit of reading aloud was much more spread than it is today, but the novel typically, written by one individual in private and read silently by another.

Printing was another crucial factor that contributed to the rise of the English novel. The modern novel was the child of the printing press, which alone can produce the vast numbers of copies needed to satisfy literate publication up rise that they can afford.

A market economy was the third factor. The sociology of the novel is based very much upon a market relationship between author and reader, mediated through publications, in contrast to earlier methods of financing publication or supporting authors such as Patronage, or subscription. A market economy increases the relative freedom and isolation of the writer and decreases his immediate dependence upon particular individuals, groups or interests.

The Rise of Individualism was also very significant in the emergence of the English novel. Ian Watt sees a typical of the novel that it includes individualization of characters and the detailed presentation of the environment. The novel is more associated with the town rather than to the village, and in some points, they are alike, for example, both involve huge numbers of people leading interdependent lives, influencing and relying upon one another.

Watt (1957), in his book, Rise of the Novel states that Defoe's "fiction" is the first, which presents us with a picture of both-individual life in its larger perspective as a historical process, and in its closer view, which shows the process being acted out against the background of the most ephemeral thoughts and action.

Furthermore, Sanders (1999: 303) says that the claim made the successive generations of literary historians and critics whom Defoe is the first true master of the English novel who has a limited validity. His prose fiction, provided in his late middle age, sprang from an experimental involvement in other literary forms; most notably the travelbook. His novels included elements of all of these forms. Nor was he the only begetter of a form which it is now recognized had a long succession of both male and female progenitors. He may in Robinson Crusoe, have perfected an impression of realism by adapting the Puritan selfconfession narrates to suit the mode of a fictional moral tract, but he would in no sense have seen fiction as superior to, or distinct from, his essays in instructive biography.

Moreover, Richetti (2005: 174) claims that no one can say what led Defoe at 59 to write a long narrative pretending to be the memoirs of a shipwrecked English planter from Brazil on a deserted island off the coast of South America. After Harley's fall from power in 1714, Defoe's epistolary record goes nearly blank, and we have little to go on for those five years until Robinson Crusoe appears in 1719. We do know that Defoe was not idle; he was never that, and indeed writing was his main livelihood. Having been recruited by the Whig ministry to act as a subversive mole within the Tory opposition press, he wrote extensively for what Novak identifies as 'the most forceful anti- government newspaper', the Weekly Journal, or Mist's Weekly Journal, so called after its editor, Nathaniel Mist. Also among the various pamphlets and tracts he published separately from his periodical journalism in those years, he found time to write the substantial and very popular conduct book in dramatic. But in 1719 Defoe had never done anything quite like Robinson Crusoe, no fiction so elaborate, no narrative so devoted to evoking the life of a private person with no topical or political importance, and no extended prose narrative so seemingly separate from political polemic and religious controversy, although there are clearly religious themes as well as political implications in Crusoe's narrative.

Richetti also states that the latter, especially, dragging out for modern readers and are never obviously polemical. There is, in retrospect however, inevitability in Defoe's turning to extended narrative fiction in the third decade of the 
eighteenth century. As we have seen, he had a native talent and deep attraction for narrative. The Review and much of his other political journalism are often enough full of narrative and vivid dramatic impersonation. There are a number of shorter works. Moreover, from the second decade of the eighteenth century that represented finger exercises in preparation for what can now be seen as his later career as a writer of imaginative fiction. These are political tracts that have a basic narrative form of an insignificant but occasionally interesting sort.

\section{Daniel Defoe and the Significance of Robinson Crusoe}

Skilton (1977) states that Robinson Crusoe is certainly the first novel in the sense that it is the first fictional narrative in which the ordinary person's activities are the centre of continuous literary attention. Before that, in the early eighteenth century, authors like Pope, Swift, Addison and Steele looked back to the Rome of Caesar Augustus (27 BC$14 \mathrm{AD}$ ) as a golden age. That period is called the Augustan age. Literature was very different since it focused on mythology and epic heroes. However, to what extent can Robinson Crusoe be called the "first novel" and how is it different from all that have been done so far? Besides, what are the evolutions in the novel genre leading to Victorian novels, like Pride and Prejudice published almost one hundred years later (1813) in terms of style, themes and concerns?

Augustan writers, before Daniel Defoe, were very protective of the status quo and their novels were philosophical and religious, based upon a myth of the eternal fitness of things. By contrast, Defoe stood for revolutionary change, economic individualism, social mobility, trade, and freedom of consciousness. For Swift, Defoe was 'the fellow who was pilloried; I have forgotten his name'. He represented at once a social literary and intellectual challenge to the Augustan world, and the Augustans reacted to him accordingly.

In Robinson Crusoe, Defoe deals with major points of Western civilisation like trade, mercantile capitalism since at that time, a great attempt was made to dominate other continents, spread culture, beliefs, like, for example, when Robinson tries to convert Friday into Christianity, as he considers him a savage. In the eighteenth century, Britain economically depended on slave trade, which was abolished on the early 1800s. Therefore, Daniel Defoe was familiar with this practice, even though he did not active criticise it. There is consequently, no surprise that, Robinson treats Friday as his slave.

However, Crusoe was able to recognise Friday's humanity, though he does not see his slavery as a contradiction. Robinson Crusoe was written within a context of a European colonialism well established around the globe.

Next, material wealth is a sign of prestige and power in Robinson's mind. For instance, he often lists his belongings, like the amount of land ploughed. His provisions and he stores the coins found on various wrecks. On top of that, he calls his 'base', his 'castle', and eventually considers himself a 'King'. Therefore, material power is an important element as well as religion and faith in the novel. Robinson rejects his father's advice and religious teachings at the beginning of the novel, in order to travel and have some adventure and wealth. Although, his shipwreck can be considered as a moral punishment and his disobedience as a sin, the protagonist did accumulate wealth and did survive at the end of the novel. Thus, the fact that he was punished can be argued and discussed. Robinson's opinion about religion is very clear.

$\mathrm{He}$ is a semi-puritan figure and tries to spread his convictions on the island to convert into Christianity. Friday, who is very rational. The hero simply refuses Friday's own beliefs, thinking that his religion is the best one. This thought may be due to the fact that British people believed that they had a right and a duty to transmit their knowledge, culture and Skilton continues and says that Robinson Crusoe was written in the first-person singular. As a consequence, we constantly have Robinson's point of view and opinion about the events happening. We have to wonder whether the protagonist, through which the story is described, may be reliable or not, and if we can trust him. If we had Friday's point of view instead, it is clear that we would have a complete different opinion about Robinson.

Probyn states that Chales Gildon, in his book, Defoe's First Substantive Critic, interpreted Robinson Crusoe as an allegory of Defoe's Defoe's own life, but Ian Watt endorses the economic theorists' view of the novel as illustrating homo-economicus and the rise of economic individualism. Not everyone insisted on seeing this novel as a metaphor: Lesclie Stephan's essay of 1868 reported that Crusoe was a ' book for boys rather than men', short of any high intellectual interest ... One of the most charming of books'. It is essentially, of course, a superb adventure story charged with the primary appeal of all narrative fiction: suspense, individual, resourcefulness, threatening disasters, an eventual triumph. Even Dr. Johnson wished it had been longer, Robinson, like Gulliver after him.

\section{Conclusion}

To sum up, there were attempts to write novel but those attempts were not as much successful perhaps due to the elements of the work and the style of the work but Defoe and other novelists with the help of reading public, the rise of the middle-class, printing as well as travelling made the emergence of the novel successful. No doubt, the rise of the novel has developed because of the existence of the romance and picaresque novels.

\section{References}

[1] Andrew, Sanders. The Short Oxford History of English Literature. Oxford: Oxford University Press 1999.

[2] Thorny, G. C., and Gwyneth Roberts. An Outline of English Literature. New Ed. Harlow: Longman, 1984. 
[3] Ian, Watt. The Rise of the Novel. Berkeley: University of California Press, 1957.

[4] John, Richetti. The Life of Daniel Defoe, Malden, MA: Blackwell, 2005.
[5] Clive, T. Probyn. English Fiction of the Eighteenth Century 1700 - 1789 London and New York: Longman, 1992.

[6] Skilton, David. The English Novel: Defoe to the Victorians. Newton Abbot: David and Charles, 1977. 